\title{
Race, Disability and COVID-19: A DisCrit Analysis of Theological Education
}

\author{
Barbara A. Fears
}

Citation: Fears, Barbara A. 2021. Race, Disability and COVID-19: A DisCrit Analysis of Theological Education. Religions 12: 35. https:// doi.org/10.3390/rel12010035

Received: 2 December 2020 Accepted: 29 December 2020 Published: 7 January 2021

Publisher's Note: MDPI stays neutral with regard to jurisdictional clai$\mathrm{ms}$ in published maps and institutional affiliations.

Copyright: () 2021 by the author. Licensee MDPI, Basel, Switzerland. This article is an open access article distributed under the terms and conditions of the Creative Commons Attribution (CC BY) license (https:// creativecommons.org/licenses/by/ $4.0 /)$.
School of Divinity, Howard University, Washington, DC 20008, USA; barbara.fears@howard.edu

\begin{abstract}
The coronavirus pandemic of 2020 has generated public debate and private discussion about systemic racism in contemporary U.S. society and the ill preparedness and misdirected focus of clergy responding to this crisis. Later research will reveal reasons trained clergy called denominational offices, requesting assistance to address the needs of patients and parishioners, and initiated lawsuits demanding to gather for worship against medical advice and government mandates. While theological educators cannot anticipate every emergency awaiting graduates, U.S. history records national crises (i.e., hurricanes, mass shootings, BLM protests, etc.) that repeat. Practical theology course offerings, course content and course assignments, therefore, should be designed to prepare students to lead in anticipation of personal and communal tragedies. As professors introduce students to theory/theorists, we must also create space for the development of critical consciousness about and praxis for: problem solving, advocacy, race relations, relationship building, crisis management, identity politics, privilege, implicit curriculums and race-based disparities in health care, policing, religion, education, etc. Critical Race Theorists assert that this nation's colonial past still plagues contemporary behaviors, employing the framework of Disability Studies and CRT (Dis/Crit), I analyze theological education to address what has been identified as racial paterfamilias in the institution, which may explain our colonial/capitalist response to COVID-19.
\end{abstract}

Keywords: Critical Race Theory; Disability Studies; privilege; colonial expansion; theological education; practical theology; religious education; coronavirus; racial paterfamilias; capitalism

\section{Introduction}

In my first year as an assistant professor in theological education, I co-taught a ministerial leadership course with my homiletics colleague in which we allowed students to choose a church management/administration or pastoral care scenario for a ministrybased project. Students repeatedly selected the church development option rather than the pastoral care alternative of ministering to persons experiencing loss (i.e., layoff, divorce, death of a family member, etc.). As an academically trained religious educator and Clinical Pastoral Education (CPE)-trained chaplain with over ten years of experience providing pastoral care to the sick, dying and bereaved in both hospitals and hospice and to inmates at maximum security male facilities, I was troubled that students routinely chose to expand their denominational footprint by building bigger barns rather than by ministering to or on behalf of persons experiencing a life crisis, when the latter are far more likely occurrences for most ministers than a building expansion.

More recently, a progressive-to-liberal biblical studies professor said to me that no one can preach from the first three chapters of the Book of Hosea because the imagery of nakedness and prostitution are too violent and too sexist, and there is no good news. I shared this Old Testament professor's observation with several Black seminary trained colleagues and friends. We all took exception to the word, "no one". As descendants of enslaved Africans, the word "no one" for us discounts the life and legacy of our spiritual and biological Black foremothers whose naked bodies were exposed on auction blocks and in breeding farms. Moreover, these naked Black women were labelled promiscuous, 
lascivious, and insatiable as justification for sexual assault. Untold numbers of them gave birth as a consequence of sexual violence, yet were able to provide hope in a dark season via hush harbors and the Invisible Institution. That hope from a bygone era that legally sanctioned oppression against Black bodies laid the foundation for the Black Church that provides good news to many today. "No one" thus insults Black and brown intestinal fortitude, spiritual and intellectual capabilities and sends the all too familiar message of white supremacy/white normativity, translated to our Black ears as "if whites cannot do a thing, then surely "no non-white/non-person" can do it. There were at least five clergy among us who had preached some pericope from the opening passages of that prophetic book.

These experiences are not unique to my institution but are representative of two sides of the teaching/learning exchange within theological education. Students enter theological education with embedded theologies-beliefs and behaviors about ministry that are informed by numerous sources of information and of misinformation from family relationships, socio-political norms, media messaging, public opinion, and denominational expectations. The professor, on the other hand, illustrates an implicit curriculum-an attitude that affects her explicit curriculum. ${ }^{1}$ As professors in theological education, our task is to help students refine, reshape, and reimagine their understanding of and commitment to their call, not set limits on their capabilities. In fact, professors are to encourage students to expand their ability to view ministry differently, more comprehensively, more inclusively through critical engagement with the scholars and pillars of faith in our respective disciplines and in dialogue with their lived realities. For example, a lawyer friend recently shared that he had not given much thought to female preachers prior to his seminary education. Now his perspective on this subject has been expanded and he has become an ally for women in ministry. He credits his seminary professors for this shift in his thinking. Theological educators, in other words, complement and challenge the spiritual formation and development of Sunday School, Bible Study and personal experiences of our students by introducing them to historical-critical scholarship and by employing exercises in practical applications to create conscientization (critical consciousness) and praxis (reflection and action upon the world in order to transform it). ${ }^{2}$ If our pedagogical approaches only call for regurgitation of knowledge (i.e., banking) without contextual analysis, then we fail to offer students the opportunity to reimagine ministry as was done for my friend or if we set limits on student abilities such as to preach good news from a difficult text, then we perpetuate what Willie James Jennings labels racial paterfamilias: the rule of the planation father over the family or of the master as the organizing center of domestic and public life. ${ }^{3}$ Racial paterfamilias in theological education, according to Jennings, is an ecclesial reality inside a white patriarchal domesticity, shaped by an overwhelming white masculinist presence that always aims to build a national and global future that we should all inhabit. ${ }^{4}$

Reflecting upon his years as both professor and Divinity School Dean, Jennings proffers that the slave legacy of Western education, especially theological education, is lodged deeply in our educational imaginations, setting our work of formation inside a pedagogy of the plantation. ${ }^{5}$ Standard operating procedures of the plantation during U.S. chattel slavery not only controlled Black bodies-that is who worked in the house or in the field and in what capacity-but also sought to control the thoughts and beliefs of the enslaved as well. For example, enslaved Blacks were taught that service to whites was mandated by God and that God and the white man were the same. ${ }^{6}$ The image or possibility that theological education is reminiscent of the colonial plantation system in the

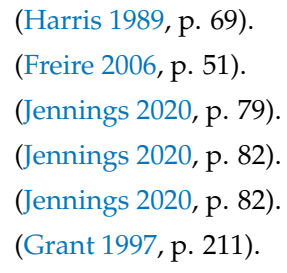


U.S. is troublesome, problematic and necessitates immediate dismantling. Writer and Black feminist poet Andre Lorde reminds us that the master's tools will never dismantle the master's house. She, therefore, suggests that we embrace difference. Difference, however, suggests that there is something normative against which we are being compared — that is different from what or who. In order to dismantle the plantation mentality of theological education that would have us build bigger barns when people are hurting, believe there is something we cannot do because it may be too hard for some, or allow hegemonic forces to be the normative, we must employ pedagogical practices that require students to analyze contexts. For example, Critical Race and Disability Studies theorists assert a race/ableness bias suggesting that in the U.S. context, students should analyze race, racism, power and ableism in scholarship and practice. The U.S. response to the coronavirus pandemic exemplifies racial paterfamilias of which Jennings speaks and offers a metaphor for analyzing the same in theological education.

Using the co-construction of Critical Race Theory (CRT) and Disability Studies (DS), I conduct a Dis/Crit analysis of the U.S. response to the coronavirus pandemic and offer suggestions for reimagining race, racism, power and ableism in theological education by making explicit the role that race, racism, power and ableism can have in the scholarship selected for our course content and application.

\section{Race Matters}

Critical Race Theory (CRT) began as a movement in the 1970s among legal scholars and activists in response to the slow implementation, even rollback, of several initiatives from the 1960s Civil Rights Movement. Although the movement began in the field of law, CRT has spread to other disciplines including politics, gender studies, ethics, health care, education, and religion. CRT advocates challenge notions of race, racism, and power, and question claims of objectivity, neutrality, colorblindness, meritocracy and the postracial state.

Some fundamental claims of CRT are that race is a social construct, that racism is endemic to U.S. society and that socio-politically sanctioned racist practices from the past that created advantages for whites and corresponding disadvantages for people of color still operate to this very day. To support these assertions, CRT advocates point to the many statistical disparities between whites and other racial/ethnic groups in education, health care, imprisonment, employment, wealth, etc., as evidence of the systemic racism reflected in contemporary practices, access, and opportunities. CR theorists also assert that there is little incentive for whites to dismantle this racist system because: (1) rich whites profit financially by holding onto the reins of power as CEOs and politicians while lowerincome whites profit psychologically by feeling better about outranking Blacks on some mythical racial hierarchy; and (2) rich whites benefit more from civil rights legislations via interest convergence than the racially oppressed for whom initiatives were designed to assist. CR theorists also challenge terms such as objectivity, neutrality, meritocracy, post-racial and colorblindness as misnomers, since these words ignore the long history in which certain racial identities were denied equal access to the privileges of whiteness (i.e., citizenship, education, housing, employment, health care, etc.). These concepts simply do not exist in practice because whites/whiteness is considered normative, the standard bearer against which all others are judged. Moreover, Blacks and other people of color live with pejorative labelling (i.e., inferior, lazy, criminal, etc.), reinforced through imaging by white-controlled media (i.e., movies, books, advertising and word choices when news reporting or politicking). As such, Blacks are not viewed through an objective, bias-free lens. Nor do Blacks come to the table with a presumption of merit. In fact, a white-owned newspaper, the Kansas City Star, issued an apology admitting its role in negatively portraying Blacks and advancing a particular narrative that reinforced Jim Crow laws, redlining and thereby robbing an entire community of opportunity, dignity, 
justice and recognition. ${ }^{7}$ Dog whistle politics, that is word choices such as Welfare Queen, inner city, urban, and anchor baby, operate much like Jim/Jane Crow Segregation laws of the past in prohibiting access to so-called "white spaces". The intent of this coded language, like the advantage/disadvantaged practices, are to maintain white hegemonic dominance over people of color. Afterall, there is a direct and abiding connection between the maintenance of white supremacist patriarchy and the institutionalization via mass media of representations of race. ${ }^{8}$

CR theorists also assert that race is a legal construct. The law's construction of whiteness defined and affirmed the critical aspects of who is white, what benefits accrue to that status and what legal entitlements arise from that status. ${ }^{9}$ For CRT legal scholar Cheryl Harris, white skin/whiteness is a property right that confers tangible and economically valuable benefits to those who meet the strict standard of proof. ${ }^{10}$ Noting that during the era of U.S. chattel slavery, white skin was the mark of a free person with civil liberties as compared to Blacks who were property of another with no civil rights, she concludes that whiteness became the quintessential property of personhood ... and meets the functional criteria of property whereby the law has accorded holders of whiteness the same privileges and benefits accorded holders of other types of property. ${ }^{11}$ This subsequent cost of white skin as property has been to devalue, even to dehumanize otherness and to ensure advantages for white persons. "Owning white identity as property affirmed the self-identity and liberty of whites and conversely, denied the self-identity and liberty of blacks". ${ }^{12}$ As such, whiteness is vigorously guarded as evidenced by the changing laws and morphing rhetoric that continues to uphold white supremacy/white advantage in response to any real or imagined civil rights advancement for people of color (i.e., Jim/Jane Crow laws in response to the Civil War and post-racial rhetoric in response to the election of the nation's first Black president). Knowledge also has been seen to be the domain/property of whiteness by proclamation and by design. For example, according to Thomas Jefferson, third president of the U.S., Blacks are inferior to whites in reason and in imagination. ${ }^{13}$ And for many generations, Blacks were denied formal education, in fact, forbidden to read.

Disability Studies came of age in the 1990s. As with most disciplines, debates ensued over definitions, causes, approaches to study, etc. Some researchers, for example, subscribed to the "medical model", where disability was biological, physically located in the person. Others believed in a "social model", suggesting that society disables people via biases and social ordering.

When the impairment is viewed as a social construct, then the impairment is viewed relationally to what and/or who is considered "normal". Here the abled are considered normal. We, therefore, compare people with a physical impairment to persons without an impairment and, by virtue of this social construction of hegemonic normalcy, create a hierarchy that also assumes not just physical ability (i.e., run, see, walk, etc.), but also presumes to reflect intelligence and human inferiority. This social construction too presumes white/whiteness as the normative. For example, some Disability Studies scholars have argued that disability is like race inasmuch as persons have been relegated to a subordinate position in society because stereotypes about their capacities counsel that they lack the ability to be productive, valuable members of society. ${ }^{14}$ Simply put, society has taken the

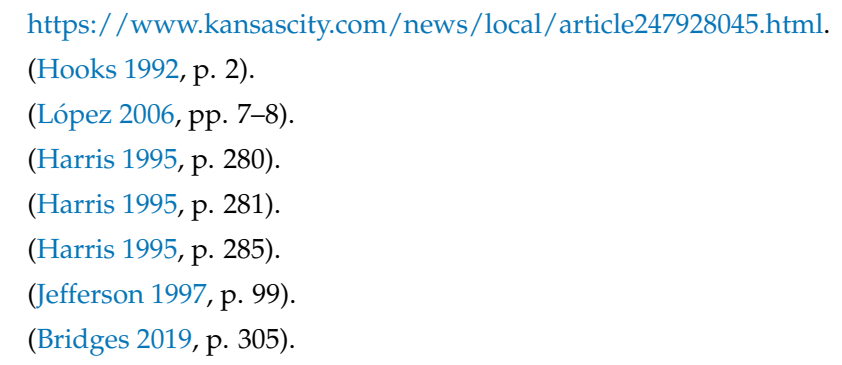


fact of racial otherness to be a sign of mental or physical deficiency and taken mental or physical deficiency to be a sign of racial otherness. ${ }^{15}$

Within DS, children can be diagnosed with an intellectual disability (ID) formerly called mental retardation, a learning disability (LD) or an emotional disturbance (ED). ${ }^{16}$ Blacks are more often diagnosed with ID, which corresponds with the historical stereotype of intellectual and mental deficiency. "African American students continue to be three times as likely to be labeled mentally retarded (or ID), two times as likely to be labeled emotionally disturbed, and one and a half times as likely to be labeled learning disabled, as compared to their White peers". ${ }^{17}$ Bridges notes, moreover, that unlike blood tests or scans to detect physical ailments, students are diagnosed with ID, LD, or ED by an evaluator who concludes that the student significantly deviates from the norm. White children, by contrast, are more often diagnosed with a learning disability, indicating that they have the potential to learn despite having low test scores. This LD diagnosis also reflects the stereotype of white intellectual superiority.

DisCrit examines ways that students of color are both raced and disabled, and thus examines race and ability, normal/abnormal, and abled/disabled. Of note is the overrepresentation of people of color in special education and their separation from the mainstream student population. A disability status justifies segregation and unequal treatment, ${ }^{18}$ which can be especially problematic for people of color raised with a sense of community. The same can be said about liberation-oriented scholarship of persons of color in theological education when they are not integrated fully into the curriculum, but are separated from classical/traditional, thinkers and considered elective classes or recommended readings. DisCrit scholars assert that a complete understanding of ableism requires an analysis of the lives of disabled people and a complete understanding of racism requires an understanding of disabled people of color. ${ }^{19}$ Like CRT, DisCrit considers the historical and legal aspects of disability and race, recognizes whiteness and ability as property and notes gains for people with dis/abilities have been made as the result of interest convergence of white, middle-class citizens. ${ }^{20}$

\section{The Master's House}

To reiterate, Jennings likens theological education to the colonial plantation of U.S. chattel slavery. He says, the slave legacy of Western education, especially theological education, is lodged deeply in our educational imaginations, setting our work of formation inside a pedagogy of the plantation. ${ }^{21}$ The image of the master/slave relationship of the plantation during U.S. chattel slavery is not a particularly flattering one, especially attributed to the educational process. Despite revisionist history characterizing enslaved Africans as "immigrant workers", 22 suggesting a willfulness to relocate for employment opportunities, slave life was brutal according to slave narratives. Mere survival required self-denial and complete focus upon the personal comfort and wealth building desires of the master. Jennings, in fact, notes that slavery taught us how to build, ${ }^{23}$ which is reflected by select responses to the coronavirus pandemic in the U.S.

As 2020 draws to a close, the U.S. has surpassed 19 million cases of coronavirus and 341,000 deaths. ${ }^{24}$ The impact of ill-advised holiday travel is yet to be revealed as hospi-

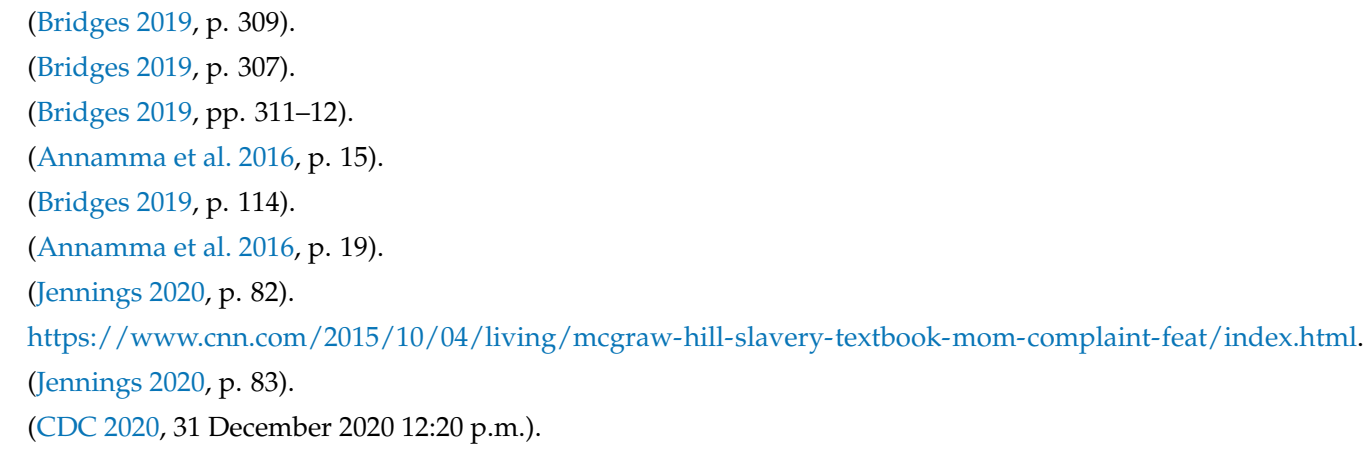


talizations and deaths are a lagging indicator of exposure. The surge in cases from other super-spreader events and the failure of many to wear masks have already overwhelmed hospitals and funeral homes in big cities and in rural communities, in red states and in blue states. According to the Centers for Disease Control and Prevention (CDC), hospitalization is 4.0 times higher for Native Americans, 3.7 for Blacks and 4.1 for Hispanics/Latinos than for whites, whereas death is 2.6 times higher for Native Americans, 2.8 for Blacks and for 2.8 Hispanic/Latinos. ${ }^{25}$ Access to health care, occupation, socio-economic status, and co-morbidities are contributing factors to these risk disparities. Persons who contract the disease and survive may have lingering health challenges for quite some time that may become pre-existing conditions when seeking future insurance coverage, and those who die may die alone. Inmates are placing the deceased into freezer truckers. ${ }^{26}$ While two vaccines have been approved recently for distribution, there is concern about their widespread availability and widespread public willingness to take the medication, especially among Black people mindful of experimentation on Black bodies. In addition to the medical challenges, small business owners and individual workers are suffering financial loss due to government mandates limiting hours of select business operation and/or total loss of work hours. People are concerned about paying rent, buying food, and caring for aging parents and school-aged children, some of whom are not doing as well academically in an on-line education environment. A new federal coronavirus relief package has been signed after being allowed to expire, which will cause a one-week benefit delay for recipients. Still a disgruntled segment of the population, including clergy, have sued in various states across the country for the civil right to reopen businesses and places of worship, and to go "maskless" despite scientific and medical community pleas to minimize in-person exposure and to wear masks in order to reduce the spread of the disease. The demand to gather for worship places untold thousands at risk and is believed to be fueled by a decline in giving, as though the decline is a reflection of attendance rather than income loss. In the immediate notification of the pandemic, schools were shut down in March 2020. However, there were some debates and even some campus-based education during the fall 2020 semester. In other words, the U.S. response to the pandemic exemplified the slave legacy of Western education. Our focus was on building rather than on ministering to the least, the lost and the left out. There was a federal relief package-corporations received millions, individuals and families making under a certain dollar amount received $\$ 1200$ and $\$ 500$ per child. Thus, the pandemic response offers insights informative to teaching and learning in theological education as characterized by Jennings.

The U.S. response to the pandemic suggests whose knowledge, interests and experience are valued/normalized. The voices of maskless protesters and litigants normalized and prioritized the interests of the hegemony and abled. The protesters and litigants seemed to take the word of a bankrupted businessman over the informed recommendations of an esteemed scientist regarding the COVID-19 risk factors and prevention measures. Something comparable often occurs in theological education. We force students both by program curriculum requirements and course content to demonstrate mastery of classical or traditional-translated European and Euro-American scholars as the standard bearer, when their insight has not been analyzed for context or applicability to the people the student will serve. White scholarship, therefore, becomes the great "unsaid", thoroughly studied and understood without the admission that traditional European and Euro-American scholarship has a context, an interest, an agenda, and a particular perspective that may have limited applicability to persons of color. In fact, European and Euro-American pastors, bible scholars and theologians have reinforced prevailing political, social, and economic structures that historically have been devastating to communities of color. ${ }^{27}$ Of course, many early texts were written by European and Euro-American scholars since people of

25 (CDC 2020, 10 December 2020)

26 https://www.theguardian.com/us-news/2020/nov/22/el-paso-coronavirus-inmates-national-guard.

27 (De La Torre and Floyd-Thomas 2011, p. xxv). 
color were excluded from the discourse. Yet some of this scholarship has been influential in liberation theology. James Cone, for example, admits to using Karl Barth and Paul Tillich to say what he believed to be the truth of the gospel as defined by the black experience. ${ }^{28}$ Required courses as well as the scholarship by European and Euro-American must be analyzed for race, racism, and power inequities including ableism. In addition, courses specific to and scholarship of persons of color must be included as equally "normative" that is required, not electives courses or supplemental readings.

Whether speaking as a head of state, head of a Divinity School or head of the class as it were, persons in positions of power speak with authority and with the presumption of believability. Suggesting that "no one" can preach from particular passages of scripture as the OT professor said to me might hold sway for some people. When a professor speaks words of low expectation or incapability to a student, he/she reflects not only an implicit curriculum, but also communicates the DS idea of intellectual disability or mental deficiency especially if spoken across racial lines to a person with a racial identity that bears the stereotype of intellectual inferiority. Therefore, professors must be attuned to our physical embodiment as non-written text and the message it communicates in the teaching/learning exchange. Talking heads do have bodies and these bodies, along with other bodies in the classroom, speak volumes. ${ }^{29}$ Moreover, since we teach who we are, according to Parker (1998), part of our call is to be self-aware, especially of our biases and blind spots as we engage our student's educational journey. "The teacher is never gender neutral, never racially neutral, never culturally neutral, never class neutral, never neutral in sexual orientation".$^{30}$ Rather, we enter the teaching/learning space as embodied beings with personal preferences and lived experiences shaped by our social location in a particular time and space. Our intersectional identities give us a particular worldview that we must acknowledge as we seek to enhance student ministerial preparedness for hands-on work anywhere in the U.S.A. (i.e., churches, hospitals, schools, prisons, agencies, etc.). Completing the Implicit Association Test (IAT) at https:/ / implicit.harvard.edu/implicit or having conversations with confidants may help to reveal biases of which we may be unaware. Having this personal self-awareness and recognition of the resulting power dynamics are essential for enabling students to likewise reimage and refine their own sense of self by becoming aware of and sensitive to practices and beliefs that historically marginalize persons in church and society by some socially constructed identity marker. In so doing, we empower students for competent and comprehensive ministerial leadership and pastoral care in crisis. Moreover, we do well to reflect upon our teaching, as recommended by Brookfield (2017), through the eyes of students, faculty, theory, and personal experience.

As CRT and DisCrit suggest, race and ableness are social constructs where whiteness is considered normative- the standard against which all other racial/ethnic identities are judged. Therefore, terms like objective, neutrality, colorblindness, meritocracy and post-racial are not race-neutral terms as alleged. They are terms intended to uphold white normativity and advantage in socio-political practice, access and opportunities. Whiteness is also considered the property right of whites alone - against which any "usurper" must be removed from so-called "white spaces". Whiteness as property is a marker of a superior people with the right to exclude. ${ }^{31}$ This mythology is rooted in Enlightenment Era pseudoscience and false theology created by philosophers and pastors to support race-based claims of white biological superiority and a God-ordained right to rule. These race-based claims of the slave-holding past still inform contemporary U.S. society by providing life-affirming stereotyping of white cultural identity and life-negating stereotyping of Black life. Not only do the statistical disparities between whites and people of color in health care, education, wealth, etc., suggest a perceived value difference in white life and Black disposability, so

8 (Cone 1999, p. 82)

9 (Pinn 2008, p. 94).

(Westfield 2001, p. 125).

31 (Douglas 2015, pp. 40-42). 
do the actual beliefs and practices. In fact, when white college students were asked what compensation they would expect should they have to endure the remainder of their lives as a Black person, the students requested $\$ 1$ million per year. ${ }^{32}$ The ability to attach a dollar amount to a fictional race transformation suggests the value these college students placed upon their white racial identity. Denial of racial biases and morphing manifestations of various means to maintain white hegemonic dominance are further evidence of the value whites place upon their racial identification. White fragility, for example, is a powerful means of white racial control and the protection of white advantage. ${ }^{33}$ Also, consider this difference in practice: a peaceful Black Lives Matter (BLM) protest is met with police officers in riot gear, tear gas and rubber bullets, ${ }^{34}$ while armed white militia confront police and insist on entry into the Michigan House floor to protest the stay-at-home orders to protect life during a pandemic. ${ }^{35}$ The vastly different government response to these two protester groups, the former primarily Black and the latter primary white, suggests a granting of acceptability/normativity to the second. In addition, coded rhetoric upholds white right to exclude in much the same way as overtly discriminatory laws (e.g., Jim/Jane Crow, and redlining). Assignments should, therefore, apply course content to real-life situations, what Freire calls the lived reality of the students, and again include analyses of race, racism, power and ableism. As a chaplain, I remind students that when visiting a patient, we are perceived as the able-bodied providing care to someone who may be feeling vulnerable because the person is temporarily bed bound post-surgery. Students must be mindful that power can shift or compete by social location. For example, while I may experience oppression in one segment of society (i.e., racism), I can experience power in another setting (i.e., ableness). As professors, we are to increase the attentiveness and self-awareness of our students, encourage them to be safe, but to also dismantle oppressive conditions in all manifestations. This task requires students to examine critically the coded language that shapes our worldview and would have us to believe that we operate from a perspective of objectivity, neutrality, colorblindness, meritocracy or a post-racial state. These concepts cannot, do not exist where, as CRT intellectual father Derrick Bell asserts, racism is an integral, permanent, and indestructible component of society. ${ }^{36}$

\section{Conclusions}

While I do not begrudge anyone having a stable income or a comfortable lifestyle, or even experiencing congregational growth, prioritizing denominational expansion over health safety or over providing pastoral presence to embodied flesh in distress is too reminiscent of European colonial expansion where wealth building of a new nation was prioritized at the expense of stolen Native American land and enslaved African labor. The prevailing attitude that justified dehumanization and established the colonial state still informs contemporary U.S. practices. As theological educators, we must recognize the impact these past practices have today upon our industry, as suggested by Jennings, namely that we have not reckoned sufficiently with the racial character of institutional life in the colonial West and, because of this failed reckoning, we have never fully understood how distorted our work of building has been. ${ }^{37}$ Nevertheless, we are yet charged to enable students to minister to people in dark times, people whose spiritual nakedness may be exposed, people experiencing personal and communal loss via car accidents, disease, downsizing, divorce, hurricane, mass shooting, or yet another police killing of an unarmed Black person whose emotions are raw. These experiences reveal vulnerabilities of faith and are far more frequent occurrences requiring pastoral care than church expansion

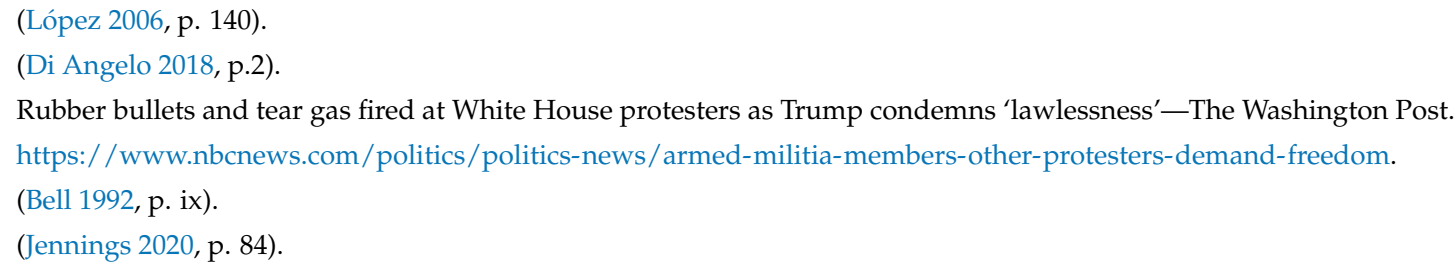


and require a different mindset than the rule of the planation building. We must build relationships instead. Thus, we must engage critical pedagogies that enable self-awareness and embrace humanity, not differences, suggesting a normative from which I am not alike, a willingness to sit with pain, heartbreak, distress; be comfortable with discomfort; or, in faith language, develop the ability to stay at the crucifixion without racing too quickly to the resurrection. Such pedagogies should acknowledge and engage socially constructed identities including race, gender, and abilities (among others). Failing to provide our students with opportunities for critical engagement that acknowledges embodied existence with the realities of race, racism, ableism and power differences across risks disabling our students from refining, reshaping and reimaging their understanding and commitments to ministry upon entering our institutions and then learning to provide comprehensive and competent pastoral care, especially in crises as a consequence of theological education. For example, we do our students a disservice if we fail to teach that racism is systemic and rooted in theological othering that began in European colonial expansion, reflected in our institutions and in many of the historical-critical writings of the pillars of the faith who may have failed to include or distorted or silenced voices of the people they colonized. We risk disabling our students if we are not mindful of our implicit curriculums. We do not help students reimage a more inclusive ministry by giving credence to whiteness as the standard bearer and ignoring whiteness as a property right with the privilege of exclusion. Persons of color can provide more than just physical labor to the upbuilding of a nation!

Funding: This research received no external funding.

Institutional Review Board Statement: Not applicable.

Informed Consent Statement: Not applicable.

Data Availability Statement: Not applicable.

Conflicts of Interest: The author declares no conflict of interest.

\section{References}

Annamma, Subina A, David J. Connor, and Beth A. Ferri. 2016. Dis/ability Critical Race Studies (Dis/Crit) Theorizing at the Intersections of Race and Disability. In DisCrit Disability Studies and Critical Race Theory in Education. Edited by David J. Connor, Beth A. Ferri and Subini A. Annama. New York: Teachers College Press.

Bell, Derrick. 1992. Faces at the Bottom of the Well: The Permanence of Racism. New York: Basic Books.

Bridges, Khiara M. 2019. Critical Race Theory: A Primer. St. Paul: Foundation Press.

Brookfield, Stephen D. 2017. Becoming a Critically Reflective Teacher. San Francisco: Jossey-Bass.

Centers for Disease Control and Prevention (CDC). 2020. COVID-19 Data Tracker. Available online: https:/ / covid.cdc.gov/covid-datatracker/\#cases_casesper100klast7days (accessed on 10 December 2020).

Cone, J. H. 1999. My Soul Looks Back. Maryknoll: Orbis Books.

De La Torre, Miguel A., and Stacey M. Floyd-Thomas. 2011. Beyond the Pale: Reading Theology from the Margins. Louisville: Westminster John Knox Press.

Di Angelo, Robin. 2018. White Fragility Why It's So Hard for White People to Talk About Racism. Boston: Beacon Press.

Douglas, Kelly Brown. 2015. Stand Your Ground: Black Bodies and the Justice of God. Maryknoll: Orbis Books.

Freire, Paulo. 2006. Pedagogy of the Oppressed. New York: Continuum.

Grant, Jacqueline. 1997. The Sin of Servanthood. In A Troubling in My Soul: Womanist Perspectives On Evil \& Suffering. Edited by Emilie M. Townes. Maryknoll: Orbis Books.

Harris, Cheryl. 1995. Whiteness as Property. In Critical Race Theory: The Key Writings That Formed the Movement. Edited by Kimberlé Crenshaw, Neil Gotanda, Gary Peller and Kendall Thomas. New York: The New Press.

Harris, Maria. 1989. Fashion Me a People: Curriculum in the Church. Louisville: Westminster/John Knox Press.

Hooks, Bell. 1992. Black Looks Race and Representation. Boston: South End Press.

Jefferson, Thomas. 1997. The Difference is Fixed in Nature. In Race and the Enlightenment—A Reader. Edited by Emmanuel Chukwudi Eze. Malden: Blackwell Publishers, Ltd.

Jennings, Willie James. 2020. After Whiteness: An Education in Belonging. Michigan: Grand Rapids.

López, Ian Haney. 2006. White by Law: The Legal Construction of Race. New York: New York University Press.

Parker, Palmer J. 1998. Courage to Teach. San Francisco: Jossey Bass Publishers. 
Pinn, Anthony. 2008. Reading the Signs: The Body as Non-Written Text. In Being Black Teaching Black: Politics and Pedagogy in Religious Studies. Edited by Nancy Lynne Westfield. Nashville: Abingdon Press.

Westfield, N. Lynne. 2001. Dear Sisters: A Womanist Practice of Hospitality. Cleveland: The Pilgrim Press. 